\title{
Sociology and Sustainable Development. The Most Important Areas of Interdisciplinary Research
}

\author{
Socjologia i rozwój zrównoważony. \\ Najważniejsze obszary badań interdyscyplinarnych
}

\author{
Paweł Rydzewski \\ Institute of Sociology, Faculty of Philosophy and Sociology \\ Maria Curie-Sktodowska University in Lublin, Poland \\ E-mail: p.rydzewski@umcs.pl \\ Researcher ID: A-1562-2019, ORCID: 0000-0002-8144-6340
}

\begin{abstract}
Sociology and sustainable development share many interesting areas of inquiry that offer the potential for closer cooperation between these two disciplines. The aim of the article is to examine the connections between them. The article considers the most promising areas; i.e, environmental issues (environmental sociology), quality of life (which is the key issue for the social pillar of sustainable development), and poverty (poverty eradication is the primary goal of the UN sustainable development agenda). It seems, however, that the cooperation between sociology and sustainable development has stopped at the stage of potential interdisciplinarity.
\end{abstract}

Key words: sociology, sustainable development, quality of life, poverty, environmental sociology, interdisciplinarity

\section{Streszczenie}

Między socjologią i zrównoważonym rozwojem istnieje wiele ciekawych wspólnych obszarów badań potencjalnie nadających się do ściślejszej współpracy. Celem artykułu jest pokazanie tych powiązań. W tekście wzięto pod uwagę obszary najbardziej obiecujące: sprawy związane ze środowiskiem (socjologię środowiskową), problematykę jakości życia (kluczowe zagadnienie dla społecznego filaru zrównoważonego rozwoju) i problematykę ubóstwa (likwidacja ubóstwa to podstawowy cel ONZ-owskich planów zrównoważonego rozwoju). Wydaje się jednak, że jak do tej pory współpraca między socjologią i zrównoważonym rozwojem zatrzymała się na stadium potencjalnej interdyscyplinarności.

Słowa kluczowe: socjologia, rozwój zrównoważony, jakość życia, ubóstwo, socjologia środowiskowa, interdyscyplinarność

\section{Introduction}

The complexity of sustainable development cannot be adequately addressed by research approaches and methods specific to single scientific disciplines. Sustainable development is interdisciplinary in its nature. The article was inspired by the research conducted by Schoolman et al. (Schoolman et al., 2012). They concluded that while sustainability

\footnotetext{
${ }^{1}$ The tripartite model includes three pillars of sustainable
} development: environmental, economic, and social. science was more interdisciplinary than other scientific fields, it still fell short of expectations inherent in the tripartite model. ${ }^{1}$ The pillar with the fewest articles published on sustainability - economics - is the most integrative, while the pillar with the most articles - environmental sciences - draws the least from outside disciplines. The analyses by Schoolman et al. show that if sustainability research 
is to live up to its interdisciplinary ideals, researchers must be provided with greater incentives to draw from fields other than their own (Schoolman et al., 2012, p. 67). ${ }^{2}$

The analyses conducted by Schoolman et al. are quantitative, bibliometric, and are based on numbers. I was interested in a different approach - a more qualitative and more in-depth one (obviously within reasonable limits, as a thorough analysis would require a book of its own). Inevitably, it was necessary to narrow the scope of the analysis. In this aspect, the choice was not difficult. For me, as a sociologist who has been dealing with sustainable development for years, the choice was obvious: sociology and sustainable development.

The article therefore aims to show the relations between sociology and sustainable development. As there are quite a few of them, only selected areas are discussed. In my opinion, the most important include: environmental issues (there is a relatively new subdiscipline of sociology - environmental sociology), quality of life (the key problem for the social pillar of sustainable development), and poverty (eradicating poverty is the primary goal of the UN sustainable development agenda).

These issues constitute a potential field of interdisciplinary cooperation. As for potentialities, the aim of the article is also to point out those areas of inquiry where the interdisciplinary cooperation is not just possible but desirable, although the possibilities are not yet fully exploited. The starting point for our considerations must be at least a brief reflection on the issue of interdisciplinarity in science. This brief overview is necessary from the point of view of the conclusions at the end of the article.

\section{Multidisciplinarity and interdisciplinarity}

Three types of research can be distinguished depending on when the integration of knowledge takes place in the cognitive process. These are: quasi-multidisciplinary, multidisciplinary, and interdisciplinary research. In quasi-multidisciplinary research, knowledge is integrated only after the research conducted in individual disciplines, in their respective languages and with different research methods and techniques, has been completed. A synthesis of knowledge comes down to putting together the research results of particular disciplines. This is a mechanical synthesis, and apart from providing information about research results, it does not bring about real progress in science. In multidisciplinary research, a common area of inquiry is usually divided into parts that are examined by specific disciplines.

\footnotetext{
${ }^{2}$ It has been more than 8 years since Schoolman et al. published their research, but as my overview of the subject literature and areas of inquiry shows, it seems that little has changed in this respect. Much has been written worldwide on the topics discussed here to keep track of all the publi-
}

Each of these disciplines is autonomous in carrying out its research tasks; i.e., it employs its own methods and language. The fact that the research results from particular disciplines are synthesised only in the final stage of the research affects the quality of these results. Depending on the specific nature of each discipline and broad research context, the cognitive value of integrated knowledge varies - it may be similar to the knowledge obtained from the quasimultidisciplinary research results (in a pessimistic scenario), or that obtained in the interdisciplinary research (in an optimistic scenario). By combining cognitive properties of specific disciplines into one whole, multidisciplinary research, at least potentially, offers greater cognitive possibilities when compared to quasi-multidisciplinary research (Wierzchosławski, 1996).

In interdisciplinary research, a research model is developed, and this model is common to all the disciplines involved and intersecting with each other. In interdisciplinary research, it is necessary to formulate a problem in such a way that it will be shared by the researchers involved and to define a common methodological framework for different aspects of this problem. Methodologies and assumptions of individual disciplines are combined and modified so that they are better suited to the needs and so that new tools are developed that would allow to address complex research issues in a scientific way (Bremer, 2016).

In interdisciplinary research, knowledge is integrated continuously, and not only in the final stages of the cognitive process (when empirical material is compiled and examined). A synthesis of knowledge in such research begins in the first stages of the research process and continues throughout it. Common basic concepts, language, etc. are adopted from the very beginning by representatives of various disciplines who carry out a given study, and these are applied in all stages. Therefore, the results of interdisciplinary research are not a simple sum of partial knowledge, as it is the case in multidisciplinary and quasi-multidisciplinary research (Wierzchosławski, 1996).

At present, still another level of scientific integration is distinguished, namely transdisciplinarity. This term is used to refer to the research where non-academics (e.g. stakeholders, decision-makers, etc.) are involved in the whole interdisciplinary research process. These people are able to correctly formulate research questions related to their situation or activity. However, a transdisciplinary approach is criticised by some academics who question the scientific quality of practical and action-oriented research. Therefore, one of the challenges is to develop a model of

cations, therefore my point of view is selective and probably subjective - to some extent. On the other hand, when observing general trends, one can come to a similar conclusion that no significant change has taken place in recent years. 
cooperation between scientists and non-scientists, while maintaining research independence and an autonomy from the potential influence of various interest groups (Ouahyb Sundsbø et al., 2015).

Some researchers go a step further and emphasise the need to shift from an interdisciplinary approach to a transdisciplinary collaboration that implies the use of concepts or methods originally developed by one discipline but now widely used by other disciplines. Since transdisciplinarity combines scientific and non-scientific experience, it is thus seen as the highest form of bringing together different disciplines and practical solutions (Bremer, 2016).

\section{Environmental sociology}

Mainstream sociology in the 70s was almost oblivious to environmental problems that were a source of concern for society at that time. This stemmed, among others, from the aversion to earlier controversies on biological and geographical determinisms that had led sociologists to ignore the biophysical world (Dunlap, Catton, 1979). For example, as recently as the late 1970 s, sociologists of agriculture argued that it was inappropriate to take into account factors such as soil type and rainfall in explanations of soil conservation adoption or farm energy use, because these were not social variables (Dunlap, Martin, 1983). These disciplinary traditions were reinforced by the fact that modern industrialised societies seemed to be increasingly disembedded from the biophysical world. Sociology began to assume that the exceptional features of the human species such as language, technology, science, or culture, made these societies exempt from the constraints of nature (Catton, Dunlap, 1980). While not denying that human beings were an exceptional species, the precursors of environmental sociology argued that humans' special skills and capabilities did not exempt them from the constraints of the biophysical environment. The emergence of environmental sociology as a distinct area of inquiry was accelerated by problems connected with shortages of natural resources, in particular energy resources. This heightened the awareness that the environment was more than just another social problem and that environmental change can indeed have social consequences, as well as the obvious fact that human activities can have an impact on the environment. Studies on the impact of energy shortages on society facilitated a transition from an early sociology of environmental issues to

\footnotetext{
3 The New Ecological Paradigm scale (NEP), which measures basic beliefs such as the existence of ecological limits and the importance of maintaining a balance of nature, is a good case in point here. It has become the most widely used measure of environmental concern employed in studies worldwide.
}

environmental sociology focused explicitly on societal-environmental relations. The emerging environmental sociology of the 1970s was quickly institutionalised via the formation of organisations within the US national sociological associations (Dunlap, Marshall, 2007).

These groups provided an organisational base for the emergence of environmental sociology as an area of specialisation and attracted scholars interested in all aspects of the environment. The late 70 s was a vibrant era of growth for environmental sociology, followed by a short period of stagnation in the 1980s. However, by the late 1980s and early 90s environmental sociology was not only reinvigorated, but also institutionalised in countries throughout the world and within the International Sociological Association (ISA) (Dunlap, Catton, 1994; Dunlap, Marshall, 2007).

In summary, environmental sociology includes or included (in the past) the following research areas (Dunlap, Marshall, 2007):

- Research on the characteristics of large environmental organisations and their members;

- Long-term historical analyses of the growth of environment conservation organisations;

- Research on the level of public awareness of environmental problems and support for environmental protection efforts;

- Conceptualisation and measurement of environmental concern; ${ }^{3}$

- Explaining the attitude-behaviour relationship in the environmental domain;

- Research into the role of media in generating societal attention to environmental problems;

- Developing a theoretical perspective of social constructivism; ${ }^{4}$

- Explaining the sources of and long-term analyses of environmental degradation;

- Identifying real and potential social impacts of shortages of energy and of other natural resources;

- Formulating solution proposals in the field of environmental protection;

- $\quad$ Research on the global spread of legal regulations concerning environmental protection.

It is not surprising that with such a wide spectrum of research, environmental sociologists frequently col-

\footnotetext{
${ }^{4}$ Sociologists have long argued that certain phenomena that have all the characteristics of social problems do not automatically become social problems unless they are defined as such by claims makers who are then successful in having their definitions publicised by the media, legitimised by policy-makers and thus placed onto the public agenda.
} 
laborate with climate scientists, geographers, limnologists, economists, political scientists, urban planners, historians, legal scholars, anthropologists, psychologists, and biologists (Pellow, Brehm, 2013). This enables them to develop a much more reliable description of socio-ecological reality.

It seems that social attitudes towards the environment, including attitudes towards environmental protection constitute one of the best researched areas of inquiry in environmental sociology. The research in this area has concerned knowledge, attitudes, as well as behaviour and declared behaviour in relation to environmental protection. It has been conducted both nationally and internationally, in relation to entire societies or specific social groups. Even a partial review of the research carried out on this subject would significantly exceed the scope of this article. For an overview of the subject literature, see (e.g. Marcinkowski, Reid, 2019).

\section{Quality of life}

Quality of life is now considered to be the main category of sustainable development. There have been many attempts to determine what constitutes quality of life. It is commonly accepted that happiness, satisfaction and well-being belong to a more subjective dimension of the quality of life, while the standard of living or welfare are treated as a more objective dimension (Sobol, 2019).

A growing interest in quality of life in social sciences can be observed in the 1950s, when the term was increasingly used in disciplines such as sociology, economics, social policy, medicine, and psychology. In the 1960s and 70s, the concept was viewed in a quantitative perspective and was employed in research on the level of satisfying individual and collective needs. Efforts were made to determine the level of consumption of various goods necessary to satisfy basic needs. At the turn of the 1980s, researchers increasingly used the concept of quality of life for sociological and psychological measurements (Trzebiatowski, 2011). In social sciences, quality of life was combined with categories such as lifestyle, subjective well-being, or one's satisfaction with life conditions and ability to fulfil basic needs.

The work of American researcher Angus Campbell constituted an important stage in the development of research on the quality of life (Campbell, 1976). He analysed the state of research on social indicators as a source of knowledge about the societal quality of life. His aim was to answer the question of how people lived and how they assessed their lives. At that time, the research was based mainly on economic (most frequently monetary) data and indicators, which were relatively easy to obtain and process. Social indicators complemented economic ones, but they could only be used to measure objective aspects. (Petelewicz, Drabowicz, 2016). Campbell suggested filling in this gap with subjective indicators, focusing on how individuals and communities assessed their quality of life. He emphasised that it was necessary to refer to an individual's sense of satisfaction in order to answer the question about their quality of life (Campbell, 1976).

Two decades later, 27 definitions of quality of life were examined and it was concluded that the majority of them covered 5 dimensions: emotional wellbeing $(85 \%)$, health $(70 \%)$, family and social relations $(70 \%)$, material well-being $(59 \%)$, and work or other forms of activity (56\%) (Cummins, 1996). Two more dimensions were later added to this list: a sense of security and functioning in community.

The universal and generally accepted definition of quality of life has not yet been developed in social sciences. Researchers rather attempt to conceptualise this concept, taking into account primarily the context in which it is used and the purpose of research carried out. The definitions of quality of life in social sciences can be classified into four groups. The first group includes so-called existential definitions (that draw a distinction between two life approaches to have and to be), the second group includes task-oriented definitions (self-development), the third group places quality of life in the category of satisfying needs (degree of satisfaction with different aspects of life), and the fourth one encompasses definitions that distinguish between the objective and subjective quality of life (combining these two measures with an assessment of the degree to which different needs are satisfied) (Trzebiatowski, 2011). Despite all these difficulties in determining what quality of life is, one of the most commonly used and cited definitions of this concept was formulated by the Quality of Life Group operating as part of the World Health Organisation (WHOQOL Group). According to WHOQOL, quality of life is the individual's perception of their position in life in the context of the culture and value systems in which they live and in relation to their goals, expectations, standards, and concerns (WHOQOL Group, 1994, p. 28). This definition focuses on the subjective perception and it is very close to a sociological perspective.

The goals of sustainable development in the field of quality of life were first formulated - as proposals by the World Commission on Environment and Development (WCED), established in 1983. In 2000, the United Nations (UN) agreed to achieve the eight millennium development goals (MDGs) by 2015: (1) to eradicate extreme poverty and hunger; (2) to achieve universal primary education; (3) to promote gender equality and empower women; (4) to reduce child mortality; (5) to improve maternal health; (6) to combat HIV/AIDS, malaria, and other diseases; (7) to ensure environmental sustainability; and (8) to develop a global partnership for development (Barreto Torres et al., 2019).

Some countries managed to achieve some of these goals, while others made very little progress or even 
failed to attain any of them. In this context, the MDGs have been replaced with the Sustainable Development Goals (SDGs), an extensive list of 17 goals to be achieved by 2030. These include: no poverty, zero hunger, good health and well-being, quality education, gender equality, clean water and sanitation, affordable and clean energy, decent work and economic growth, industry, innovation and infrastructure, reduced inequalities, sustainable cities and communities, responsible consumption and production, climate action, life below water, life on land, peace, justice and strong institutions, global partnership (The Sustainable..., 2019). Most of these goals are related to quality of life.

Measuring the quality of life requires various indicators that go beyond the gross domestic product (GDP), which is commonly used to assess a state's development based on its economic performance. Novacek and Mederly (2015) compiled a list of alternative indicators that can be used to measure this development.

- Index of Sustainable Economic Welfare (ISEW) is an aggregated indicator based on personal consumption, social well-being and the quality of the environment, reflecting non-monetary benefits, and the long-term costs of environmental damage. Ultimately, the ISEW as an alternative indicator of GDP failed to win recognition, which was probably due to the complexity of its calculations.

- Human Development Index (HDI) has been successful, being regularly evaluated and published by the United Nations Development Programme (UNDP) since 1990. Its strength most likely lies in its simplicity.

- Dashboard of Sustainability is composed of four main areas: environmental, social, economic, and institutional. The resulting index was calculated from 45 indicators and is expressed graphically.

- Environmental Sustainability Index (ESI) focuses on the situation of the environment and its load, human dependency on and sensitivity to external influences, social capacity, institutional capacity and participation in international cooperation. It consists of 5 themes, 21 sub-themes and 76 indicators.

- Environmental Vulnerability Index (EVI) is intended to complement the existing evaluation of economic and social vulnerability, including such factors as climate change, biodiversity, water, agriculture and fisheries, human health, desertification, and exposure to natural disasters.

- Well-being of Nations (WI) is assessed on the basis of two main components: the Human Well-being Index (HWI) and the Ecosystem Well-being Index (EWI).

- Living Planet Index (LPI) monitors trends related to biological diversity on Earth. The World
Wide Fund for Nature (WWF) monitors the situation of terrestrial and marine species.

- Ecological Footprint (EF) compares the rate of consumption of natural resources with the capacity of biologically productive areas on Earth. The ecological footprint has one undeniable advantage - it can be assessed at the global, national, local and even at the individual level.

- Happy Planet Index (HPI) gives the average number of years of a happy life per unit according to consumed natural resources; i.e., it assesses how efficiently countries transform natural resources to produce the welfare of their inhabitants, including aspects such as ecological footprint, life satisfaction and life expectancy.

- Gross National Happiness (GNH) is an attempt at defining quality of life in more holistic terms and with greater respect to the non-material aspects of life than GDP. From the very beginning, the concept has had one deficiency - it is very difficult to define happiness as it is a highly subjectively experienced condition.

- Genuine Progress Indicator (GPI) assesses whether the increased production of goods and services in a given country results in an improvement in the welfare. It takes into account the environmental costs of improving the welfare.

- Human Poverty Index (HPI) complements HDI and assesses the standard of living in a given country; developing and developed countries are evaluated separately and using different indicators: HP Index for Developing Countries and HP Index for selected OECD countries.

- State of the Future Index (SOFI) is a statistical evaluation of future development trends in relation to the economic, social and environmental dimensions, with a 10 -year outlook.

The terms happiness, satisfaction, or well-being have more subjective connotations, while the standard of living or welfare are more objective. It is worth pointing out that all these terms are used by researchers representing a variety of scientific disciplines, from economics, sociology, through medicine and psychology and many others. Furthermore, a wide interest in subjects directly or indirectly related to the quality of life research indicates the need for an interdisciplinary approach (Sobol, 2019). In recent years, a growing interest in these more subjective concepts has been observed, both when it comes to their importance and measurement methods.

In a classic review from the mid-1980s, Schuessler and Fisher listed examples of the quality of life research in sociology, grouping it into several categories (Schuessler, Fisher, 1985). These are: (1) research on the impact of basic socio-demographic characteristics (age, sex, income, marital status, socio-economic status) on quality of life, (2) research 
on the impact of participation in social life and the quality of interpersonal relations, (3) research on the quality of life among groups receiving social care (e.g. the elderly, disabled), (4) comparative national studies (e.g., comparisons between more developed and less developed regions of a given country), and (5) international comparative studies.

In the following years, an interest in quality of life in sociology grew significantly. It has become an interdisciplinary subject, supported by two major international associations, one numbering nearly $900 \mathrm{mem}$ bers, three peer-reviewed journals, four newsletters, three annual meetings, and numerous publications (just to mention, 15 volumes from one publisher). Although sociologists have not produced a large amount of research in the name of QOL, they have significantly contributed to understanding social system effects upon elements of the quality of life, such as social structure, crime, education, inequality, etc. Thus, sociologists have identified important changes in social structure that have influenced quality of life (Ferriss, 2004).

As a fairly new interdisciplinary field of inquiry, the quality of life research has benefited greatly from a cooperation with the discipline of sociology. Sociological research in this area consists of five overlapping traditions, namely 1) social indicators research, 2) happiness studies, 3) gerontology of successful ageing, 4) psychology of well-being, and 5) health related quality-of-life research. The efforts of sociologists are particularly prominent in the first two of these traditions (Veenhoven, 2007). Quality of life is also a major issue in subdisciplines of sociology: sociology of work and sociology of the family.

In subsequent years, sociologists made a significant contribution to research on quality of life, mainly on indicators of quality of life and happiness studies. In terms of methodological paradigms, the quantitative approach was prevalent, while there were slightly fewer qualitative analyses. The field of inquiry was expanded, for example, a new trend had developed that focused on circumstances that reduced the quality of life. Multivariate statistical models (mainly regression models) are increasingly used to determine the hierarchy of impact of different variables and to predict the level of quality of life based on key predictors (Bartram, 2012).

\section{Poverty}

Sustainable development can only be achieved if poverty is put to an end. The outcome document of Rio + 20 The Future We Want states that poverty eradication is the greatest global challenge facing the world today and an indispensable requirement for sustainable development. Combining poverty eradication with sustainable development, the conference points out that people are at the centre of sustainable development and new challenges must be addressed through inclusive economic growth, reducing inequalities and sustainable use of resources (UN, 2012).

The Report of the Open Working Group on Sustainable Development Goals at the $68^{\text {th }}$ session of the UN General Assembly, which took place in July 2014, sets out 17 sustainable development goals and 169 specific targets. The first of them is to end poverty in all its forms everywhere (UN, 2014a).

In December of the same year, in his synthesis report on the Post-2015 Sustainable Development Agenda, entitled The Road to Dignity by 2030: Ending Poverty, Transforming All Lives and Protecting the Planet, the UN Secretary-General emphasised that the future sustainable development should be based on rights and take people and the environment as core (UN, 2014b). The report also proposed an integrated set of six essential elements: dignity, people, prosperity, our planet, justice and partnership, to facilitate the construction and improvement of the Development Agenda after 2015 (Liu et al., 2015).

The goals included in the Millennium Development Goals constituted an important step towards the eradication of poverty in the world. These were, among others: eradication of extreme poverty and hunger by halving the proportion of people with income of less than USD 1 per day, achieving universal primary education, and halving the proportion of people who have no access to clean drinking water. However, the Millennium Development Goals were not achieved by the set deadline. Consequently, a modified action plan was adopted, which still recognised halving the number of people living in extreme poverty (on 1 or less dollar per day) and halving the number of people without access to drinking water and sanitation facilities, as the most urgent goals (United Nations, 2015).

Sociologists have long been concerned with the problems of poverty. This topic has been rooted in the history of this scientific discipline. Marx and Engels pointed to a clear division between the impoverished working class who had nothing to sell apart from their labour power and the capitalists who as the owners of the means of production, were able to use this labour power for their own profit. Max Weber claimed that it was not only economic factors that created and maintained inequalities, but also that such inequalities were perpetuated by power, status and prestige. Emile Durkheim stressed that social inequalities were necessary for the welfare of society (Shildrick, Rucell, 2015). The repercussions of these early theoretical ideas can be observed in sociological thought to this day - to a greater or lesser extent. Sociologists, however, have been more interested in explaining poverty than in measuring it, though almost all of them believe that poverty statistics are meaningful social indicators of basic needs. Sociological interests in poverty centre around the ideas of the culture of poverty and the effects of place on poverty. Roles of culture, local community, power, 
social structure, and other factors largely out of control of the individual are the main forces which sociologists use to explain poverty (Smeeding, 2002). For example, neighbourhood exerts a strong influence on the concentration of and inheriting poverty in ghettos of large cities, and thus negatively affects future life chances and long-run deprivation. In this context, we talk about neglected population of socially excluded people. Sociologists are also interested in how poverty is correlated with gender and household structure (initiation and intergenerational transmission of poverty in single-parent families). In general, sociologists are critical of the economist's perspective of free choice models whereby individuals control their own destiny and are therefore the cause of their own poverty (Smeeding, 2002).

In recent years, some have argued that social class divisions have become more complex and fuzzy and less significant for lifestyles and life experiences. It has been suggested that mechanisms for identity formation have changed, going beyond traditional class divisions and becoming more reflective of individual choice than they were in the past. It is argued that individuals now have greater control over their own destinies, and thus poverty is less a question of being born into a poor or rich family, of fate, and more of a question of choice. Consumption practices (what people buy) are often believed to be a key mechanism by which people can demonstrate their individuality and create their own individual identities. What is ignored, however, is the fact that consumption has also become an increasingly important element of social divisions: the poor find it difficult to partake in expected consumption behaviours, and their consumption patterns are different from those of people free from poverty. This is not a question of choice but of necessity. Moreover, the spending patterns of those in the greatest poverty often lead to stigmatisation by society. Consumption may seem to be an opportunity to build a lifestyle and identity that reflects individual preferences and choices, but it may also reinforce social class divisions. This mechanism not only launched the process of labelling, but also was a driver of shame associated with poverty (Shildrick, Rucell, 2015).

Although stigmatisation has long been the subject of inquiry into poverty, it has received more attention now, especially when there are premises leading to believe that people experiencing poverty reinforce stigmatisation themselves, by accepting stereotypes about the poor, and trying to dissociate from the poor (Shildrick, MacDonald, 2013).

In contemporary sociology, there are also other concepts explaining the origin and, to some extent, the persistence of poverty: (1) Culture of poverty. This concept assumes that the poorest strata of society establish an isolated and self-reproducing subculture. Culture plays an important role here, introducing a specific lifestyle and consolidating it in subsequent generations. The culture of poverty can appear in any historical situation, but it develops mainly in societies with, among others, high unemployment rates and low employment rates of unskilled people, low salaries, and where wealth, promotion and economic development are important. This subculture can survive as long as it is able to establish self-invigorating mechanisms. They are based on the attitudes, aspirations and personality of the children raised in subcultural circumstances. That is why the improvement of economic conditions does not necessarily lead to the elimination of the culture of poverty, which has its source elsewhere. It is said that it is easier to put an end to poverty than to the culture of poverty (Czibere, 2014); (2) Underclass. The term underclass was coined to describe those individuals and families who found themselves in extreme living conditions and on the margins of society. This term is used mainly to refer to the poor living in the ghettos of large cities. These ghettos are inhabited by people living on social allowances permanently or almost exclusively. Most often these are the unemployed young (mainly unemployed males) who do not attend or are excluded from school and no longer search for a job. This group also includes single and unemployed mothers who are addicted to alcohol or drugs, as well as gangs, individual criminals and homeless people (Schmitter Heisler, 1991); (3) Social exclusion. Since late 1970s, the term exclusion has become increasingly popular and it has been used to define a modern form of poverty (later the context of the term was modified and expanded). Exclusion is often understood as a lack of participation in major areas of social life (Redmond, 2014); (4) Life cycle. It has been pointed out that vulnerability to poverty is related to an individual's and in particular to family's life cycle stage. Most susceptible to poverty are families in the childbearing stage (increased expenses) and in the stage of empty nest when adult children (who for some time contributed to the family budget) leave the family home (Tuttle, 1989).

Sociology is somewhat unique in bringing the concept of inequality to the forefront (poverty should be regarded as the most striking form of inequality). The problem of inequality has always been a key focus for sociologists - what is more, a focus on inequality reaches to the core of sociology, as this is a major concern in the writings of sociology classics such as Karl Marx, Max Weber, and Emil Durkheim. Inequalities can be economic, political, institutional, racial, gender, and national - all of which are important for understanding how social systems work for the benefit of some groups and to the disadvantage of others. However, classical sociology that focuses only on interpersonal inequalities lacks a broader perspective. At this point, we should return to environmental sociology discussed above and its promise is to expand our understanding of the world taking into account not only the often tense and violent relationships among humans, but also between 
people and ecosystems, and animal species (Pellow, Brehm, 2013).

Ultimately, it is necessary to first establish the breadth and depth of this social phenomenon before it can be meaningfully analysed and its ultimate causes and remedies can be explored. Therefore, it is crucial to search for more accurate measures of poverty employed by sociologists and other social scientists in a national and broader perspective - comparisons across nations (Smeeding, 2002).

\section{Concluding remarks}

Based on a review of the literature (in particular, research literature) on sustainable development and sociology relating to environmental sociology, quality of life and poverty, I would like to make a few remarks from an interdisciplinary perspective. My impression is that interdisciplinarity in these three areas is more of a postulate and an unexplored possibility, than the reality. Let us take a closer look. Environmental sociology is a fully grown and largely institutionalised subdiscipline of sociology that employs the language and methodology of sociology. Research on the quality of life is a large and fragmented area that constitutes part of various social sciences, health sciences, etc. There is a significant body of research on this issue in sociology. The situation is similar when it comes to research on poverty although the number of disciplines that are concerned with this social problem, is much smaller.

Environmental sociology has much in common with sustainable development, but these are primarily common subjects of interest. The results of environmental sociology studies are crucial for sustainable development, but in my opinion, environmental sociology is multidisciplinary and not interdisciplinary (it can be argued how much quasi-multidisciplinary it is). Similarly, sociology has its unquestionable achievements in the research on quality of life and poverty. However, I have not been able to identify studies that would develop a research model common to sociology and sustainable development, or studies that would combine and modify the methodologies and assumptions of sociology to make them better suited to current needs and to develop new tools.

On the basis of these observations (selective and incomplete as they must be), the hypothesis can be formulated that sociology and sustainable development share many interesting areas of inquiry that have the potential for interdisciplinary research, but so far cooperation between these two disciplines has stopped at the stage of potential interdisciplinarity.

\section{References}

1. ASPE C., MARIE J., 2013, French Environmental Sociology Facing Interdisciplinary Research Across
Social and Natural Sciences, 1 st Annual International Interdisciplinary Conference, 24-26 April, Azores, Portugal, p. 315-321.

2. ATKINSON R., SWANSTROM T., 2012, Poverty and Social Exclusion, in:, The Oxford Handbook of Urban Politics, eds. John P., Mossberger K., Clarke S.E., Oxford University Press, p. 1-18.

3. BARRETO TORRES L.D., ASMUS G.F., DA CAL SEIXAS S.R., 2019, Quality of Life and Sustainable Development, in: Encyclopedia of Sustainability in Higher Education, eds. Leal Filho W., Springer, Cham.

4. BARTRAM D., 2012, Elements of a Sociological Contribution to Happiness Studies, in: Sociology Compass 6/8, p. 644-656.

5. BOSTRÖM M., DAVIDSON D.J. (eds.), 2018, Environment and Society. Concepts and Challenges, Palgrave Macmillan, p. 1-394.

6. BREMER J., 2016, Nauka o zrównoważeniu - w poszukiwaniu transdyscyplinarnej metodologii, in: Zagadnienia Naukoznawstwa, 1(207), p. 15-33.

7. CAMPBELL A., 1976, Subjective Measures of Wellbeing, in: American Psychologist, 31(2), p.117-124.

8. CATTON W. R., DUNLAP R. E., 1980, A New Ecological Paradigm for Post-Exuberant Sociology, in: American Behavioral Scientist, 24, p.15-47.

9. CUMMINS R., 1996, The Domains of Life Satisfaction. An Attempt to Order Chaos, in: Social Indicators Research, 38, p. 303-328.

10. CZIBERE I., 2014, The sociological context of poverty, in: Metszetek - Journal of Social Sciences, 1, p. 151-168.

11. DEMPSEY N., BRAMLEY G., POWERS S., BROWN C., 2011, The Social Dimension of Sustainable Development: Defining Urban Social Sustainability, in: Sustainable Development, 19(5), p. 289300.

12. DUNLAP R. E., CATTON W. R., 1979, Environmental Sociology, in: Annual Review of Sociology, 5, p. 243-273.

13. DUNLAP R. E., CATTON W. R., 1994, Struggling with Human Exemptionalism: The Rise, Decline and Revitalization of Environmental Sociology, in: American Sociologist, 25, p. 5-30.

14. DUNLAP R. E., MARSHALL B. K., 2007, Environmental Sociology, in $21^{\text {st }}$ Century Sociology: A Reference Handbook, vol. 2, eds. Bryant C.D., Peck D.L., Thousand Oaks, Sage, p. 329-340.

15. DUNLAP R. E., MARTIN K. E., 1983, Bringing Environment into the Study of Agriculture, in: Rural Sociology, 48, p. 201-218.

16. FERRISS A. L., 2004, The Quality of Life Concept in Sociology, in: The American Sociologist, 35, p. 3751.

17. GLATZER W., L. CAMFIELD V., MØLLER M. (eds.), 2015, Global Handbook of Quality of Life. Exploration of Well-Being of Nations and Continents, Springer.

18. GRAHAM C., 2018, Subjective Well-Being in Economics, in: Oxford Handbook of Well-Being and Public Policy, eds. Adler M.D., Fleurbaey M., The Oxford University Press, p. 1-30.

19. GROSS M., HEINRICHS H. (eds.), 2009, Environmental Sociology European Perspectives and Interdisciplinary Challenges, Dordrecht, Springer.

20. HANNINGAN J., 2006, Environmental Sociology, New York, Routledge. 
21. HEINRICHS H., GROSS M., 2010, Introduction: New Trends and Interdisciplinary Challenges in Environmental Sociology, in: Environmental Sociology. European Perspectives and Interdisciplinary Challenges, eds Gross M., Heinrichs H., Springer, p. 116.

22. KASPER D., 2016, Re-conceptualizing (environmental) sociology, in: Environmental Sociology, 2(4), p. 322-332.

23. LAND K.C., MICHALAOS A.C., SIRGY M.J. (eds.), 2012, Handbook of Social Indicators and Quality of Life Research, Springer, p. 1-593.

24. LEAL FILHO W., MARANS R.W., CALLEWAERT J. (eds.), 2018, Handbook of Sustainability and Social Science Research, Springer, p. 1-485.

25. LIDSKOG R., MOL A., OOSTERVEER P., 2015, Towards a Global Environmental Sociology? Legacies, Trends and Future Directions, in: Current Sociology, 63(3), p. 339-368.

26. LITTIG B., GRIESSLER E., 2005, Social Sustainability: Catchword between Political Pragmatism and Social Theory, in: International Journal of Sustainable Development, 8(1-2), p. 65-79.

27. LIU Q-Q., YU M., WANG X.-L., 2015, Poverty reduction within the framework of SDGs and Post-2015 Development Agenda, in: Advances in Climate Change Research, 6, p. 67-73.

28. LOCKIE S., 2016, Sustainability and the Future of Environmental Sociology, in: Environmental Sociology, 2(1), p. 1-4.

29. MARCINKOWSKI T., REID A., 2019, Reviews of Research on the Attitude-Behavior Relationship and Their Implications for Future Environmental Education Research, in: Environmental Education Research, 25(4), p. 459-471.

30. MURPHY K., 2012, The Social Pillar of Sustainable Development: Literature Review and Framework for Policy Analysis, in: Sustainability: Science, Practice and Policy, 8(1), p. 15-29.

31. NECKEL S., (2017), The Sustainability Society: A Sociological Perspective, Culture, Practice \& Europeanization, vol. 2, no. 2, p. 46-52.

32. NOVACEK P., MEDERLY P., 2015, How to Measure Progress towards Quality of Life and Sustainability of Life, in: Ekologia, 34(1), p. 7-18.

33. OUAHYB SUNDSBØ A., RUNKLE B.R.K., McMONAGLE S., JANTKE K., LOTTERMOSER F., GOTTSCHICK M., HASELER S., LOPEZ J. M. R., SCHEELE M., 2015, One Metaphor - Several Meanings: An Interdisciplinary Approach to Sustainable Development, in: Integrating Sustainability Thinking in Science and Engineering Curricula, eds. Filho Leal W. et al., World Sustainability Series, Springer International Publishing Switzerland, p. 197-213.

34. PELLLOW D.N., BREHM H. N., 2013, An Environmental Sociology for the Twenty-First Century, in: Annual Review of Sociology, 39, p. 229-250.

35. PETELEWICZ M., DRABOWICZ T., 2016, Jakość zycia - globalnie i lokalnie. Pomiar $i$ wizualizacja, Uniwersytet Łódzki.

36. REDMOND G., 2014, Poverty and Social Exclusion, in: Handbook of Child Well-Being, eds. Ben-Arieh A. et al., Dordrecht, Springer Science, p. 1387-1426.

37. SAUVÉ S., BERNARD S., SLOAN P., 2016, Environmental Sciences, Sustainable Development and Circular Economy: Alternative Concepts for TransDisciplinary Research, in: Environmental Development, 17, p. 48-56.
38. SCHMITTER HEISLER B., 1991, A Comparative Perspective on the Underclass, Questions of Urban Poverty, Race, and Citizenship, in: Theory and Society, 20(4), p. 455-483.

39. SCHUESSLER K. F., FISHER G. A., 1985, Quality of Life Research and Sociology, in: Annual Review of Sociology, 11, p. 129-149.

40. SHILDRICK T., MACDONALD R., 2013, Poverty talk: how people experiencing poverty deny their poverty and why they blame 'the poor', in: The Sociological Review, 61(2), p. 285-303.

41. SHILDRICK T., RUCELL J., 2015, Sociological Perspectives on Poverty, Report, Joseph Rowntree Foundation, Cambridge.

42. SMEEDING T. M., 2002, Sociology of Poverty, LIS Working Paper Series, No. 315, Luxembourg Income Study, Luxembourg.

43. SOBOL A., 2019, Quality of Life in Theory and Practice of Sustainable Development, in: Scientific Papers of Silesian University of Technology, 140, p. 351-364.

44. SØRAKER J.H., VAN DER RIJT J.-W., DE BOER J., WONG P.-H., BREY P. (eds.), 2015, Well-Being in Contemporary Society, Springer, p. 1-236.

45. The Sustainable Development Goals Report 2019, (2019), New York, United Nations, p. 1-62.

46. TRZEBIATOWSKI J., 2011, Jakość życia w perspektywie nauk społecznych i medycznych - systematyzacja ujęć definicyjnych, in: Hygeia Public Health, 46(1), p. 25-31.

47. TUTTLE R.C., 1989, Poverty Over the Family Life Cycle, in: Family and Economic Issues, 10(4), p. 267291.

48. UNITED NATIONS, 2012, The Future We Want, Rio+20 United Nations Conference on Sustainable Development, Rio de Janeiro, 20-22 June 2012, p. 172.

49. UNITED NATIONS, 2014a, Report of the Open Working Group of the General Assembly on Sustainable Development Goals, p. 1-24.

50. UNITED NATIONS, 2014b, The Road to Dignity by 2030: Ending Poverty, Transforming All Lives and Protecting the Planet, Synthesis Report of the Secretary-General On the Post-2015 Agenda, New York, p. 1-47.

51. UNITED NATIONS, 2015, Millennium Development Goals Report 2015, New York, p. 1-73.

52. WHOQOL Group, 1995, The WHO Quality of Life Assessment: Position Paper of the WHO, in: Social Science and Medicine, 4(10), p. 1403-1409.

53. WIERZCHOSŁAWSKI S., 1996, Wielodyscyplinowość $i$ interdyscyplinarność statystycznych badań zjawisk społecznych, in: Ruch Prawniczy, Ekonomiczny i Socjologiczny, 85(1), p. 85-101.

54. VAVIK T., KEITSCH M., 2010, Exploring Relationships between Universal Design and Social Sustainable Development: Some Methodological Aspects to the Debate on the Sciences of Sustainability, in: Sustainable Development, 18(5), p. 295-305.

55. VEENHOVEN R., 2007, Quality of Life Research, in: 21st. Century Sociology, A Reference Handbook, eds. Bryant C.D., Peck D.L., Sage, Thousand Oaks, p. 54-62.

56. ZIELIŃSKI T., SAGAN I., SUROSZ W. (eds.), 2018, Interdisciplinary Approaches for Sustainable Development Goals. Economic Growth, Social Inclusion and Environmental Protection, Springer, p. $1-245$. 
